\title{
Reflection on Peat Swamp Fires in Indonesia
}

\author{
Alamsyah \\ Department of Public Administration \\ Sriwijaya University \\ Palembang, Indonesia \\ (alamsyah78@fisip.unsri.ac.id) \\ Sri Suwitri \\ Department of Public Administration \\ Diponegoro University \\ Semarang, Indonesia \\ (sri_suwitri@yahoo.co.id)
}

\author{
Kismartini \\ Department of Public Administration \\ Diponegoro University \\ Semarang, Indonesia \\ (kis_martini@yahoo.com)
}

\section{Yuwanto}

Department of Political Science

Diponegoro University

Semarang, Indonesia

(yuwantosaja@yahoo.com)

\begin{abstract}
Peat swamp fires, particularly in Sumatera and Kalimantan island, Indonesia, have been occur every year. Literature study shows that this phenomenon has been attracting scientists from various disciplines of science and produced significant contribution to understanding peat swamp fires and haze disaster in Indonesia. However, these studies have ignoring the contribution of networked actor to peat swamp fires and haze disaster. In fact, empirical evidence shows that it involves many actors (local, national, and global level). In this paper, the author shows that peat swamp fires and haze disaster in Indonesia, especially in South Sumatera, can be explained using policy network perspective. Early observation on this phenomenon shows that it has been created a policy community. However, their evolution tends to opposite with Hypothesis 1 and Hypothesis 2 in Advocacy Coalition Framework (ACF). Empirical research is needed to investigate this gap more deeply.
\end{abstract}

Keywords—peat swamp; fires; haze disaster; Indonesia;

\section{INTRODUCTION}

The environment is one of the global issues facing humanity when human civilization undergoing industrialization process since the Industrial Revolution (1750-1870) [1]. In 1798, Thomas Malthus was expressed this issues through phrase: "population, when unchecked, increases in a geometrical ratio. Subsistence increases only in an Arithmetical ratio" [2]. Two centuries later, they were voiced by Limits to Growth [3] and Our Common Future [4]. Today, the United of Nations (UN) has integrated environment issues in Sustainability Developments Goals (SDGs) paradigm that replacing Millennium Development Goals (MDGs) [5], [6]. This story shows a strong multi-stakeholder commitment to environmental problems at global level.

Indonesian government has also a high political commitment to preservation of the environment (see, Constitution of Republic of Indonesia, Article 28H, Paragraph 1; Article 33 Paragraph 4). It has produced several law on environment (Law 32/2009 on the Protection and Environmental Management). It is mean that they vision has congruent with global vision on environment. Culturally, the Indonesian society is part of the Eastern culture that emphasizes harmonious principle within human-environment relationship [7]. This principle is the ethics foundation that could be found in customary law in Indonesia, for example, forbidden forest [8], sasi custom [9], taboo [10], human-plants relationships [11], or human-animal relationship [12].

This cultural capital was supported by civil society actors, which is represented by diverse non-governmental organizations who cares on environmental issues [13]. In Indonesia, the NGO has contributed substantively to increased participation, transparency, establishing an institutional framework infrastructure for the development of democracy, and change advocating [14], including preservation of the environment [15]. However, rule of law, government's participation in global initiatives, cultural capital, and the presence of civil society who are concerned with environmental issues does not ensuring the creation of a better environment. One of the environmental problems that has been consistently occur within 10 (ten) years is peat swamp fire (see Figure 1).

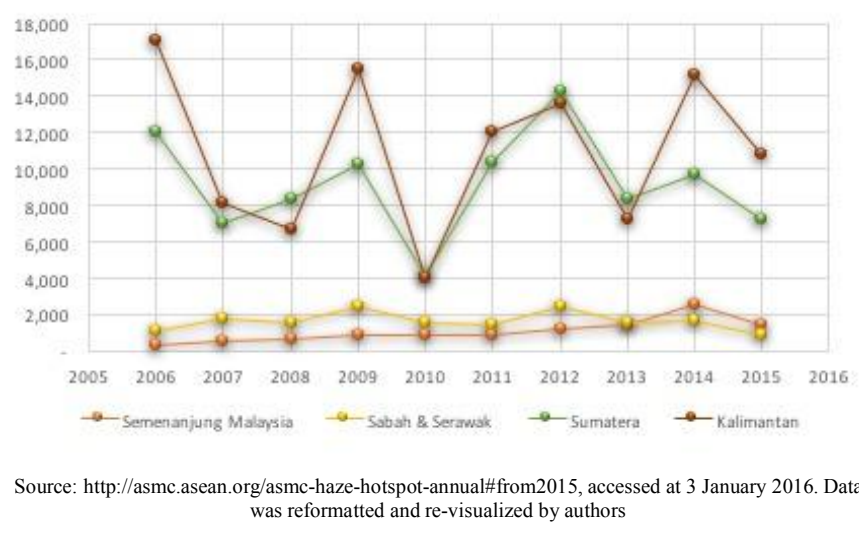

Figure 1 Hotspot progress in Indonesia and Malaysia (2006-2015) 
Peat swamp fires and haze disaster is a global environmental problem. Although Indonesian's economic growth is low, but he has the third place in the world - after the United States and China - as a contributor of greenhouse effect. This situation was triggered and created by peat swamp fires in dry season which releases more carbon dioxide into the air [16]. It disturbs population health in Indonesia, Malaysia and Singapore [17], [18]. For the ASEAN countries, particularly Singapore and Malaysia, peat swamp fires and haze disaster have a negative multipliers effect. It affects daily productive activity of people, loss of economic benefits, and burdening government budget [19], [20].

Peat swamp and haze disaster also stimulate a negative reaction from nongovernmental organization at national (i.e.: WALHI) and international level (i.e.: OXFAM) [21], [22]. It encouraged the ASEAN countries (the Association of Southeast Asian Nations) to ratify the agreement on Transboundary Haze Pollution at 10 June 2002. This ratification indicate that ASEAN country does not simply see it as Indonesian problem only, but it is a collective problem, that is, the ASEAN problem [23]. Unfortunately, after 12 (twelve) years, precisely on 16 September 2014, Indonesia became the last country who ratified this agreement.

\section{Current Findings}

Indonesia's peat swamp fires that producing haze disaster for Southeast Asian region has been investigated by several scholars from many discipline: ecology [24], [25], cultural studies [26], politics [27], [28], public policy [29], and governance [30], [31]. Although [30] and [31] using the same perspective to explaining forest conservation policy in Indonesia, but they did not include the issue of peat swamp fires and haze disaster as the object of their study. However, both of them showed that forestry sector has complex issues (involving many actors, institution, and networking) and should be explained by governance perspective.

Those studies in the above provide its own contribution to understanding peat swamp fires and haze disaster in Southeast Asia, particularly in Indonesia. However, there is no researcher explaining it based on policy network perspective. In fact, as suggested by [30] and [31], it involves multi-actors that interacting in a specific network. In the context of South Sumatera province, this network has begun growing when the European Union (EU) implementing theirs program (the South Sumatra Forest Fires Management) in 2003. EU has been facilitated this network to formulating the cause, effect, and solution of peat swamp fires by focusing interaction of land, forest, people, and corporation as a interplay factors [32].

\section{The NeXt Agenda: Applying ACF}

The policy community is successful to identify problems and alternative recommendations for peat swamp fire prevention policies. It is indicated that, according to $\mathrm{ACF}$ perspective, they have similar causal belief [33]. This situation is in line with Hypothesis 2 in ACF, that is: actors within an advocacy coalition will show substantial consensus on issues pertaining to the policy core, although less so on secondary aspects [33]. It will, then, facilitate coordination, cooperation, and produces policy output which is in line with policy belief of policy community.

In fact, this policy community was fail to translate their causal belief into real policy. It is contrast to ACF preposition which is believed that the measure of success and failure of policy communities is embedded in their ability to translating causal belief into real policy [33]. Policy option which is adopted by the Government of South Sumatera Province is simple indicator of this failure. The Government of South Sumatera Province likes to approaching peat swamp fire and hazes disaster as natural disaster than non-disaster approach [34], [35]. It is mean that the Government of South Sumatera Province has negated causal belief of policy community which consists of more non-disaster approach to managing peat swamp fires and haze disaster. This situation challenging theoretical believed, especially in governance tradition, who state that policy networking is the best treatment to remedy various problems in community [36], [37].

If we interpreted this failure as instability of policy community, then we are challenging Hypothesis 1 in ACF, that is: "on major controversies within a policy subsystem when policy core beliefs are in dispute, the lineup of allies and opponents tends to be stable over periods of a decade or so" [38]. For ACF, long term is generally understood as 10 (ten) years period or more. In our case, 2003 was considered as birth year of policy community in peat swamp fires and haze disaster in South Sumatera Province. This policy community still exists until now (2015). 2003-2015 period is 17 (seventeen) years and already meet ACF intended duration.

Instability of policy communities can also be explaining through actor's perspective on peat swamp fire and haze disaster in 2015. For example, Alex Nurdin (the Governor of South Sumatera Province) said that the primary cause of peat swamp fire is natural factors [34]. Siti Nurbaya (Minister of Environment and Forestry) said that forest fires, including peat swamp fires, are caused by people activity. In contrast to these opinion, WALHI Sumatera Selatan (South Sumatera Forum for Indonesian Environment) stated that the primary executor of peat swamp fires is plantation corporations who has controlling land through Industrial Plantation Forest (HTI) concession [39].

Based on narrative in the above, we concluded that peat swamp fires and haze disaster in South Sumatera Province can be explaining by policy networks (i.e.: ACF). Off course, ACF cannot provide practical solutions to substantive problems [33]. For the author, the ACF interpretation on dynamics of policy network is a source of inspiration for multi-parties within the network to maximize their role for influencing policy process. Empirical research is needed to prove this hypothetical statement: peat swamp fires and haze disaster, as an ecology disaster, was caused by poor governance.

\section{CONLUSION}

Peat swamp fires in Sumatera and Kalimantan island that produced haze disaster for Indonesia, Singapore, and Malaysia is a global environmental problem. Similar to others environmental problem, it has various dimensions: ecology, socio-cultural, economy, and politics. We show empirical and 
theoretical situation where policy networking in peat swamp fires and haze disaster has developed without following theoretical beliefs of ACF supporter. This situation, then, demands further scientific explanation from political scientist.

\section{ACKNOWLEDGMENT}

This paper is part of research on Policy Networking of Peat Swamp Fires Alleviation in Ogan Komering Ilir District, South Sumatera Province, Indonesia in Department of Public Administration, Faculty of Political and Social Science, Diponegoro University, Central Java, Indonesia. We want to thank you for anonymous readers who make significant contribution in the early draft.

\section{REFERENCES}

[1] M. H. Hart, Understanding human history. Georgia, USA: Washington Summit Publishers, 2007

[2] T. Malthus, An essay on the principle of population. London, U.K: J. Jhonson, 1798.

[3] D. H. Meadows, D. L. Meadows, J. Randers, and W. W. Behrens III, The limits to growth: a report for the Club of Rome's project on the predicament of mankind. New York, USA: Universe Books, 1973.

[4] G. H. Bruntland, M. Khalid, S. Agnelli, S. A. Al-Athel, B. Chidzero, and L. M. Fadika, "Our common future: Report of the World Commision on Environment and Development." United Nations, Washington D.C., USA, pp. 284-287, Apr-1989.

[5] United Nations, The Millennium Development Goals Report 2015. New York, USA: United Nations, 2015.

[6] United Nations, Transforming our world: the 2030 Agenda for Sustaianable Development. New York, USA: United Nations, 2015.

[7] D. Henley, "Natural Resource Management: Historical Lessons from Indonesia," Human Ecology, vol. 36, no. 2, pp. 273-290, 2008.

[8] G. B. Hainsworth, "Economic growth, basic needs, and environtment in Indonesia: the search for harmonious development," Southeast Asian Affairs, no. 1985, pp. 152-173, 1985.

[9] C. Zerner, "Through a Green Lens: The Construction of Customary Environmental Law and Community in Indonesia's Maluku Islands," Law \& Society Review, vol. 28, no. 5, pp. 1079-1122, 1994.

[10] L. T. Uyeda, E. Iskandar, A. Purbatrapsila, J. Pamungkas, A. Wirsing, and R. C. Kyes, "The role of traditional beliefs in conservation of herpetofauna in Banten, Indonesia," Oryx, pp. 1-6, 2014.

[11] B. Belcher, N. I. Rujehan, and R. Achdiawan, "Rattan, rubber, or oil palm: cultural and financial considerations for farmers in Kalimantan," Economic Botany, vol. 58, no. Supplement, pp. S77-S87, 2004.

[12] E. P. Riley, "The importance of human-macaque folklore for conservation in Lore Lindu National Park, Sulawesi, Indonesia," Oryx, vol. 44, no. 22, pp. 235-240, 2010.

[13] C. Heurlin, "Governing civil society: The political logic of NGO-state relations under dictatorship," Voluntas, vol. 21, no. 2, pp. 220-239, 2010.

[14] H. Antlöv, D. W. Brinkerhoff, and E. Rapp, "Civil Society Capacity Building for Democratic Reform: Experience and Lessons from Indonesia," Voluntas, vol. 21, pp. 417-439, 2010.

[15] S. Suharko, "The Success of Youth-Oriented Environmental NGO: A Case Study of Koalisi Pemuda Hijau Indonesia," Asian Social Science, vol. 11, no. 26, pp. 166-178, 2015.

[16] T. Wright, "World Bank may reward the rescue of rain forests; G-8 backs new effort to keep tropical areas in bid to help climate," The Wall Street Journal Asia, Hong Kong, p. 1, Jun-2007.

[17] A. Anonymous, "Air Pollutant Index Hits All-Time High Of 839 in Kuching," Asian Wall Street Journal, Victoria, Hong Kong, p. 11, Sep-
1997.

[18] J. M. Watts, “Singapore Grapples With 'Unhealthy’ Haze From Indonesia; Air Pollution in Singapore Reached its Most Hazardous Level This Year on Tuesday," Wall Street Journal (Online), New York, N.Y., Oct-2014.

[19] J. Hutton, "Riau's economic loss from forest fires in March hits 20t rupiah," The Business Times, Singapore, Apr-2014.

[20] I. M. Sentana, C. Fernandez, and N. Brereton-Fukui, "World News: Malaysia Haze Worse As Jakarta Fights Fire," Wall Street Journal, New York, N.Y., Jun-2013.

[21] M. Bachelard, "Office paper 'sourced from forests': Indonesia," Sydney Morning Herald (Australia). Sydney Morning Herald, p. WORLD; Pg. 15, Jul-2014.

[22] M. Rizki, R. Nofitra, I. G. Sufa, and S. Sundari, "Walhi Somasi Presiden dan Tiga Menteri | fokus | Tempo.co," Tempointeratkif.com, 2013.

[23] L. Gooch, "Choking smog blankets Southeast Asia," International Herald Tribune, Paris, p. 3, Jun-2012.

[24] E. Frankenberg, D. McKee, and D. Thomas, "Health Consequences of Forest Fires in Indonesia," Demography, vol. 42, no. 1, pp. 109-129, 2005.

[25] S. E. Page, F. Siegert, J. O. Rieley, H.-D. V Boehm, A. Jaya, and S. S Limin, "The amount of carbon released from feat and forest fires in Indonesia during 1997," Nature, vol. 420, pp. 61-65, Nov. 2002.

[26] V. Bizard, "Living with the Risk of Fire in Indonesia's Peatlands," Internationales Asien Forum. International Quarterly for Asian Studies, vol. 42, no. 1-2, pp. 319-343, 2011.

[27] H. M. Varkkey, "Malaysian investors in the Indonesian oil palm plantation sector: home state facilitation and transboundary haze," Asia Pacific Business Review, vol. 19, no. 3, pp. 381-401, 2013.

[28] H. Varkkey, "Oil palm plantations and transboundary haze: Patronage networks and land licensing in Indonesia's peatlands," Wetlands, vol. 33 , no. 4, pp. 679-690, 2013.

[29] H. B. Dulal, K. U. Shah, and C. Sapkota, "Reducing emissions from deforestation and forest degradation (REDD) projects: lessons for future policy design and implementation," International Journal of Sustainable Development \& World Ecology, vol. 19, no. 2, pp. 116-129, Apr. 2012.

[30] P. Agung, G. Galudra, M. Van Noordwijk, and R. Maryani, "Reform or reversal: the impact of REDD+ readiness on forest governance in Indonesia," Climate Policy, vol. 14, no. 6, pp. 748-768, Nov. 2014.

[31] C. van Oosten, P. Gunarso, I. Koesoetjahjo, and F. Wiersum, "Governing Forest Landscape Restoration: Cases from Indonesia," Forests, vol. 5, no. 6, pp. 1143-1162, 2014

[32] S. Suyanto, U. Chokkalingam, and P. Wibowo, "Kebakaran di Lahan Rawa/Gambut di Sumatera: Masalah dan Solusi," in Kebakaran di lahan rawa/gambut di Sumatera: masalah atau solusi, 2003.

[33] H. C. Jenkins-Smith, D. Nohrstedt, C. M. Weible, and P. A. Sabatier, "The Advocacy Coalition Framework: Foundation, Evolution, and Ongoing Research," in Theories of the Policy Process., Third., P. A Sabatier and C. M. Weible, Eds. Colorado, U.S.A: Westvew Press, 2014, pp. 4.008-4.886.

[34] Kompas TV, "Alex Noerdin Bicara Asap - AIMAN Episode 34 Bagian 5 - YouTube," www.kompastv.com, Kompas TV, Indonesia, 2015.

[35] Z. Hussain, "Indonesia to induce rain over forest fires," The Straits Times (Singapore). The Straits Times (Singapore), p. ASIA; South East Asia, Feb-2014.

[36] A. Sandström, "Policy Networks: The relation between structure and performance," Policy Studies Journal, vol. 36, no. 4, 2008.

[37] E. Sorensen, "Democratic Theory and Network Governance," Administrative Theory \& Praxis, vol. 24, no. 4, pp. 693-720, 2002.

[38] P. A. Sabatier, "The advocacy coalition framework: revisions and relevance for Europe," Journal of European Public Policy, vol. 5, no. 1, pp. $98-130,1998$.

[39] Kompas TV, "Pembakaran Lahan, Siapa Diuntungkan? - AIMAN Episode 34 Bagian 4 - YouTube," www.kompastv.com, Kompas TV, 2015. 
